\title{
AVALANCHE TARNS
}

\author{
By B. B. FitzharRis
}

(Department of Geography, University of Otago, Dunedin, New Zealand)

\author{
and I. F. OWENS
}

(Department of Geography, University of Canterbury, Christchurch, New Zealand)

\begin{abstract}
Avalanche tarns are a particular morphological form of avalanche impact and sixteen of these features are described from the Fiordland region of New Zealand. Average area of the tarns is $11000 \mathrm{~m}^{2}$. Profiles are given for eight of the avalanche paths where such tarns occur. All are found at the base of very steep avalanche tracks (slopes $38-59^{\circ}$ ), where there are no fans, so that there is an abrupt change of slope with the valley floor. The plunging avalanches which cause the tarns may have a mass of up to 300000 tonnes and impact pressures of more than $600 \mathrm{kN} / \mathrm{m}^{2}$, although no direct measurements are available.
\end{abstract}

Résumé. Les lacs d'avalanches. Les lacs (tarns) d'avalanche sont un type morphologique particulier au point d'impact d'une avalanche, seize de ces formes sont décrites dans la région de Fiordland en Nouvelle-Zẻlande. La surface moyenne de ces lacs est de $11000 \mathrm{~m}^{2}$. On donne le profil en long de 8 des couloirs d'avalanches où ils existent. Tous se trouvent à la base de couloirs en très forte pente (angles de pente de $38-59^{\circ}$ ) dépourvus de cône d'alluvion, de sorte qu'il y a un changement de pente brutal avec le fond de la vallée. Les avalanches qui se précipitent en créant des "lacs" peuvent entrainer des masses jusqu'à 300000 tonnes et produire des pressions de plus de $600 \mathrm{kN} / \mathrm{m}^{2}$ bien qu'on ne dispose d'aucune mesure directe.

Zusammenfassung. Lawinen-Bergseen. Lawinen-Bergseen sind eine besondere morphologische Form der Lawinenwirkung; 16 dieser $\mathrm{Er}$ scheinungen im Gebiet von Fiordland, Neuseeland, werden beschrieben. Die mittlere Fläche dieser Seen liegt bei $11000 \mathrm{~m}^{2}$. Fur 8 der Lawinenbahnen, an denen solche Seen auftreten, werden Profile vorgeführt. Sie liegen alle am Ende sehr steiler Lawinenbahnen (Neigungen zwischen $38-59^{\circ}$, wo keine Schuttfächer vorhanden sind, so dass sich ein scharfer Gefällswechsel am Talgrund ergibt. Die abgehenden Lawinen, welche die Seen verursachen, dürften Massen bis $300000 \mathrm{t}$ und Aufpralldrucke von mehr als $600 \mathrm{kN}$ pro $\mathrm{m}^{2}$ aufweisen, wofür allerdings keine direkten Messungen vorliegen.

\section{INTRODUCTION}

Although the geomorphic activity of snow avalanches is extensively described (for example Rapp, 1959; Luckman, 1977), little attention is given to what are here termed avalanche tarns. Good examples of these small lakes, which are located at the base of avalanche tracks, are found in the Fiordland region of New Zealand ( $\mathrm{Fig} .1$ ). The purpose of this paper is to describe these features in more detail as they have been examined in only a few cases, with those from Norway probably being the best known (Corner, 1980). They also represent an extreme form of avalanche impact. Little is known about the dynamics of such events, although Perla and others (1978) have measured the impact forces of snow falling vertically from a height of $10 \mathrm{~m}$ in small controlled experiments, and Schaerer (1962) presents equations for the impact forces of avalanches that jump a natural bench to land on a snow shed.

\section{PREVIOUS DESCRIPTIONS}

Repeated avalanche impact may produce small depressions, sometimes filled by water, which have been called avalanche scour pits (Davis, 1962), or avalanche pits (Serbenko in Peev 1966). They describe these forms as ranging up to $300 \mathrm{~m}^{2}$ in area and $9 \mathrm{~m}$ deep. Liest $\phi 1$ ([1974]) notes circular cratershaped ridges of debris thrown out of small lakes by the explosive effects of avalanche impact. In the same way, Davis (1962), when describing an avalanche scour pit on the floor of Grouse Meadow in the Kings River basin of California, presumed a snow avalanche had tumbled down the mountain and shoved soil outward and forward to form a rim; then snow melted and left behind a depression filled with water. Serbenko noted that the pits are ellipsoid in shape and are slightly inclined on their outer side towards the valley and that this was to be explained by the upheaval of the soil during avalanche impact.

Corner (1980) found that most of the avalanche impact landforms of northern Norway are located below

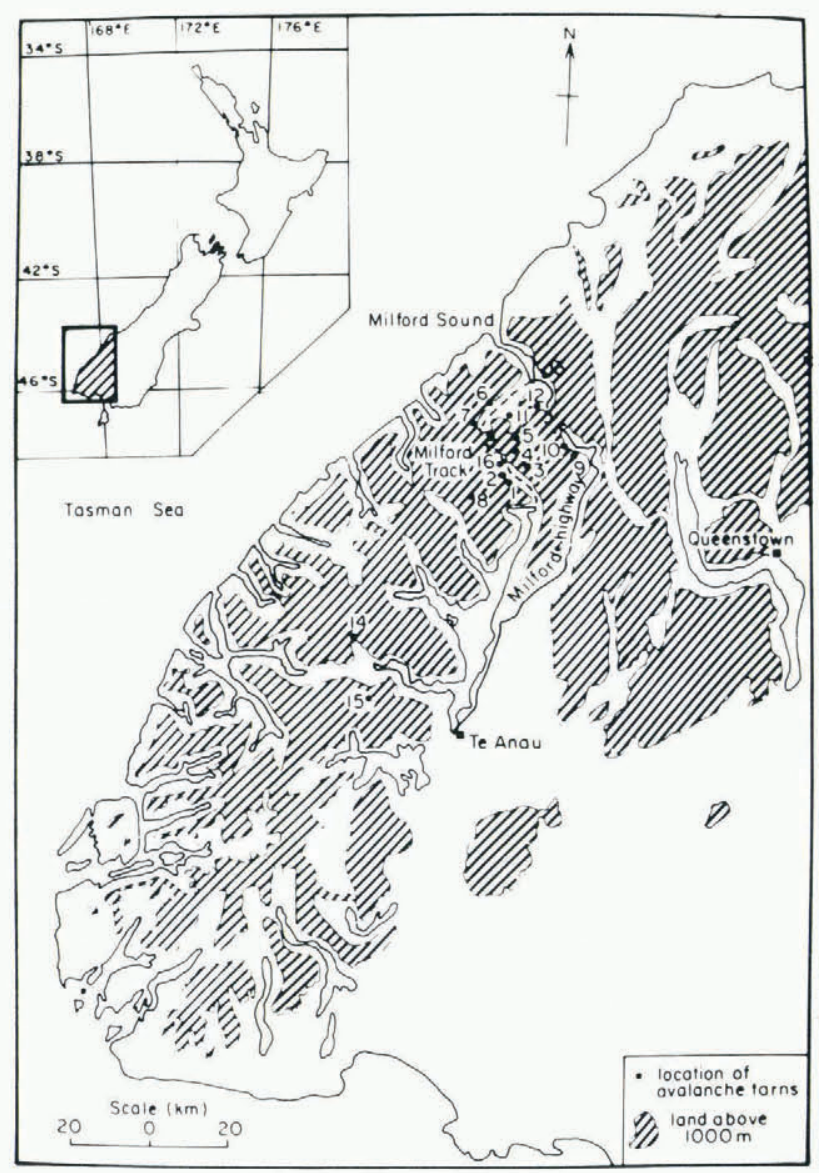

Fig. 1. The Fiordland region of New Zealand and Location of avalanche tarns. 
long avalanche chutes or gullies. He noted that three morphological varieties occur: (a) avalanche-impact tongues, which are debris accumulations on the distal banks of streams; (b) avalanche-impact pits, which are water-filled depressions; and (c) avalancheimpact pools, which are submerged depressions occurring in large water bodies such as fiords or lakes.

The avalanche tarns described here are similar to the avalanche pits of Corner, and were first noted in the Fiordland region by Smith (1947).

\section{FIORDLAND AVALANCHE TERRAIN}

The Fiordland region has been deeply glaciated, so that avalanches originating in the high cirques and shelf areas plunge down steep, convex slopes to the valley floors below (Fig. 2). Precipitation is high, averaging $6236 \mathrm{~mm} /$ year at Milford Sound, and $6747 \mathrm{~mm} /$ year at Wilmot Pass (New Zealand Meteorological Service, 1973). These two factors combine to produce avalanches that occur along the valleys with a density of $160 / \mathrm{km}$ year (Smith, 1947).

The avalanche-starting zones of Fiordland have characteristics that are similar to those elsewhere.
Of 41 avalanche paths that cross the Milford Road, the average area is $0.1 \mathrm{~km}^{2}$ with a range from 0.008 to $0.861 \mathrm{~km}^{2}$, and the average slope is approximately $40^{\circ}$, ranging from $29^{\circ}$ to $59^{\circ}$. Almost half originate on areas of permanent snow. Most starting zones are above $1500 \mathrm{~m}$ a.s.1, an elevation which often marks the lip of the glacial trough, and extend up to $2500 \mathrm{~m}$ a.s.1. (Fitzharris and 0wens, 1980).

In contrast, the tracks appear to differ significantly from those reported from many other avalanche areas, undoubtedly as a result of the strongly oversteepened glacial valley slopes. For example, the mean slope of the 41 tracks is over $50^{\circ}$, much steeper than that for the San Juan Mountains, U.S.A. (Miller and others, 1976), and most tracks are usually steeper than starting zones.

The run-out zones generally consist of steep fans or bedrock areas, but some are flat river beds especially in the larger, more extensively glaciated valleys. Vegetation patterns often show the effects of extensive wind blast and of direct snow impact. Because of the moderating influence exerted on the climate by the nearby Tasman Sea, it is unusual for the run-out zones to be snow covered, even in winter, when the snow-line usually fluctuates about an elevation of $1000 \mathrm{~m} \mathrm{a.s.1.}$

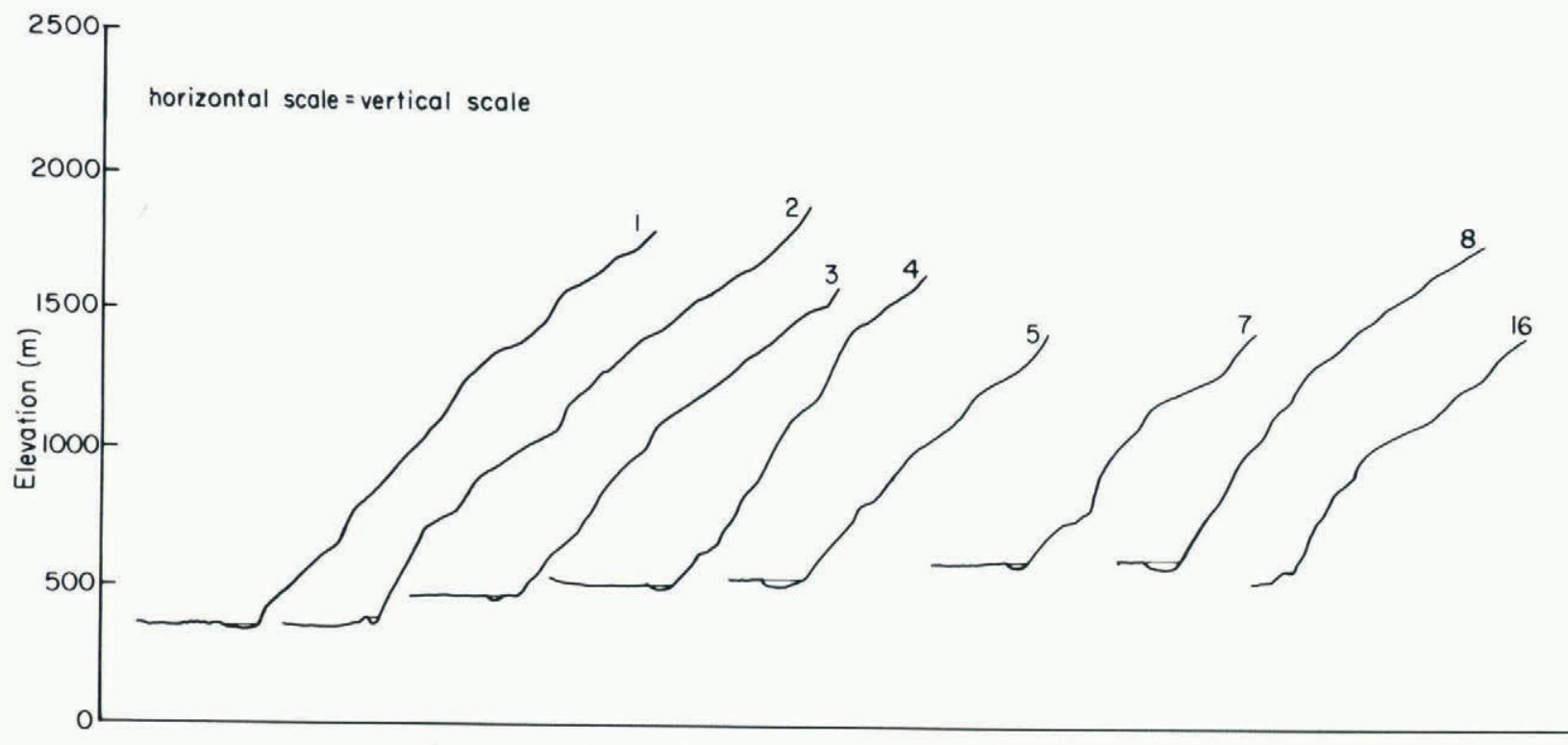

Fig. 2. Profiles of some avalanche paths with tarns.

TABLE I. FIORDLAND AVALANCHE TARNS

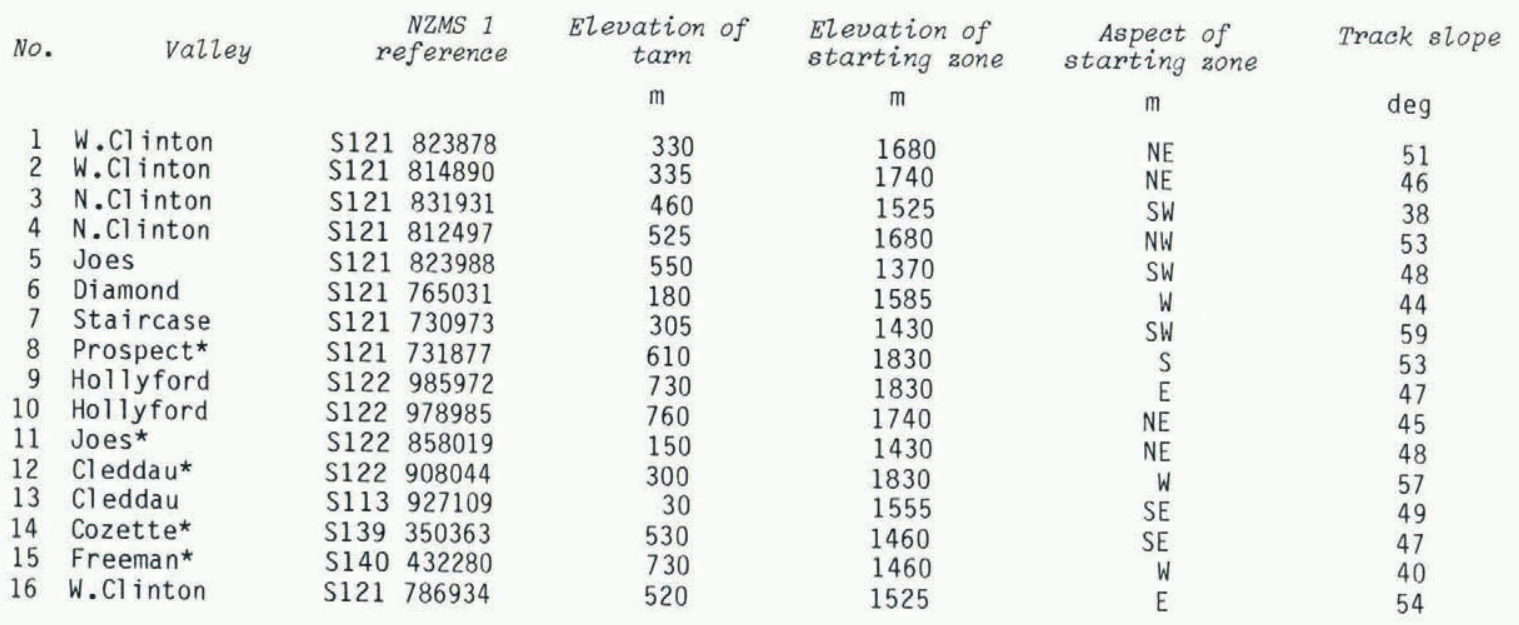

* identified from map inspection only 


\section{AVALANCHE TARNS IN FIORDLAND}

Eleven avalanche tarns were recognized from field inspection, either from a helicopter or on the ground, with a further five identified from topographic maps (Fig. 1. Table I). In total about $10000 \mathrm{~km}^{2}$ of southwest New Zealand was searched. The tarns tend to be centred around the most heavily glaciated part of Fiordland, with many easily observed from the Milford highway or from the Milford Track. Despite the continuation of glaciated terrain into southern Fiordland, they are less common there because the mountains become lower, and receive less snow. Likewise, although high and glaciated terrain continues to the north and east, there are no avalanche tarns because the bedrock geology changes from resistant granites, gabbros, and gneisses, which favour steeper slopes, to softer alpine schists and lower-grade metamorphic rocks. These erode more readily and form valleys with less spectacular walls.

The tarns have a variety of shapes. Some are circular, while others are elongated parallel or at right angles to the valley. They vary from minor lakes of dimension $300 \mathrm{~m} \times 150 \mathrm{~m}$ (No. 7), to small ponds $20 \mathrm{~m} \times$ $10 \mathrm{~m}$ (No. 16). The largest avalanche tarn covers

$50000 \mathrm{~m}^{2}$ and the smallest $200 \mathrm{~m}^{2}$. Since the mean area of the tarns listed in Table $I$ is $11000 \mathrm{~m}^{2}$ (standard deviation 16 000), they are much larger than the five avalanches pits described by Corner (1980), who notes that the biggest and morphologically most striking pit in north Norway is Rundvatnet, an almost circular avalanche tarn about $8000 \mathrm{~m}^{2}$ in area. However, his largest avalanche pools are bigger, being c.200-300 m across, or up to $70000 \mathrm{~m}^{2}$ in area.

The Fiordland avalanche tarns occur on the valley floors, so occupy a range of elevations. All are 10cated close to valley sides at the base of avalanche paths with slopes ranging from $38-59^{\circ}$. Those shown in Figs 2-6 are good examples.

Vertical profiles of some of the avalanche paths were compiled from those areas mapped at a scale of 1 : 14000 ( $F i g .2$ ), and a contour map of the avalanche path and tarn at Hidden Lake, a popular lunch place for walkers on the Milford Track, is shown in Figure 3. While the slopes of the tracks are steep by most standards, and steeper than the $15-40^{\circ}$ reported for avalanche impact pits by Corner (1980), they are not unusual for Fiordland. Likewise, the elevations of the starting zones are similar to other avalanche paths of the region, ranging from $1370 \mathrm{~m}$ to $1740 \mathrm{~m} \mathrm{a.s.1}$, and having a wide variety of aspects. Thus the reason why a few avalanche paths produce avalanche tarns, but most do not, is not immediately obvious from their morphological characteristics.

\section{FORMATION OF AVALANCHE TARNS}

There is good evidence to support the notion that the tarns described in Table I are a product of ava1 anche impact. They all occur near the base of steep tracks, where there is an abrupt change of slope with the valley floor. Patterns of damage and vegetation succession radiate from the base of the avalanche tracks. In 1982, tarn No. 2 of Table I, known locally as "the swimming pool", was struck by a large ava1 anche which destroyed vegetation over an area of about $10000 \mathrm{~m}^{2}$, and by its impact pushed up gravel debris as concentric ridges on the valley side of the tarn (Fig. 5). These observations are consistent with those of impact pits reported from el sewhere by Davis (1962), Liestøl ([1974]), and Corner (1980). At the nearby Hidden Lake (Figs 3 and 4), similar, but older features are found on a larger scale, together with

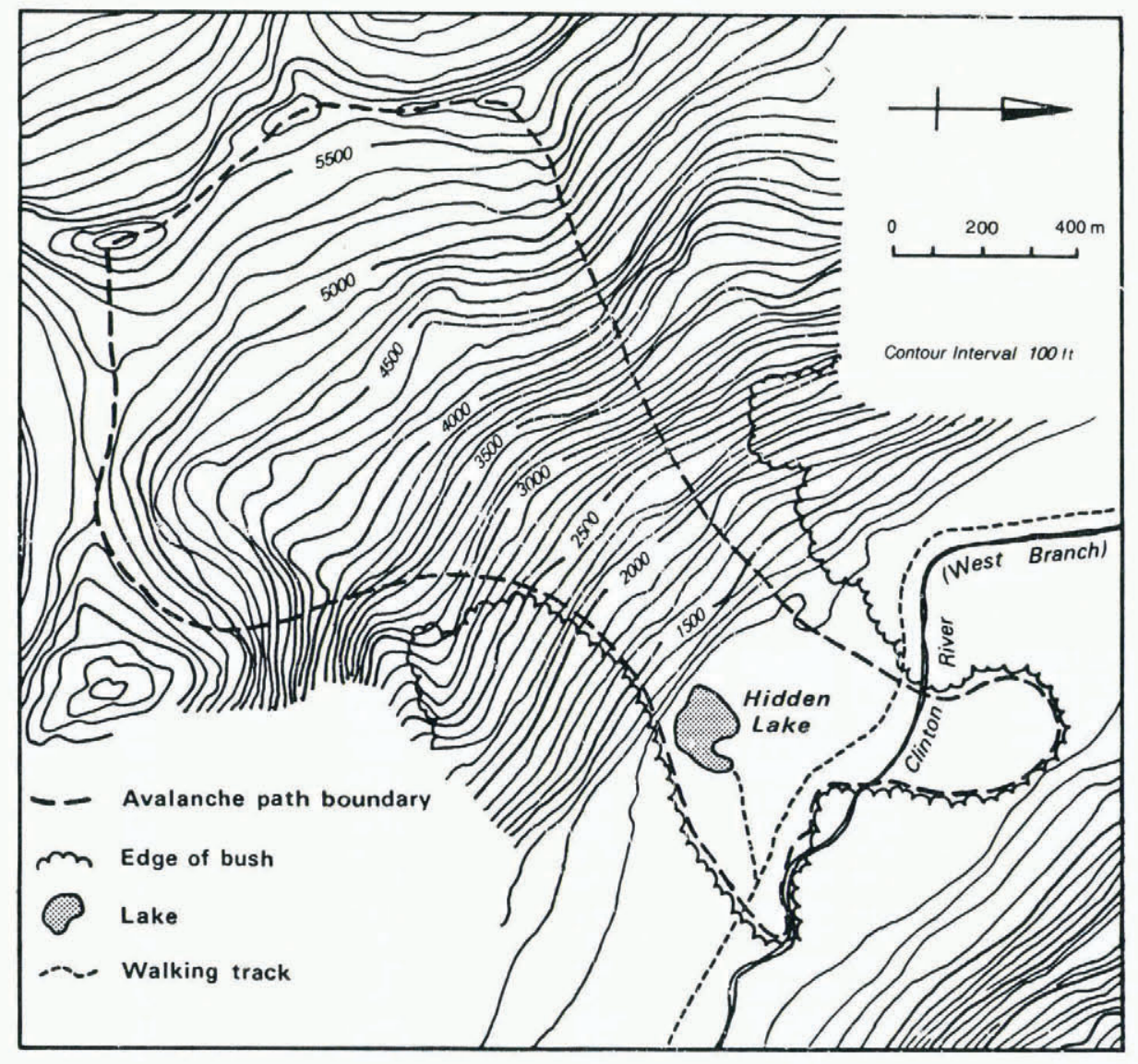

Fig. 3. Detailed contour map of an avalanche path and tarn. The photograph of this tarn is shown in Fig. 4 and data given in No. 1 Table $I$. 


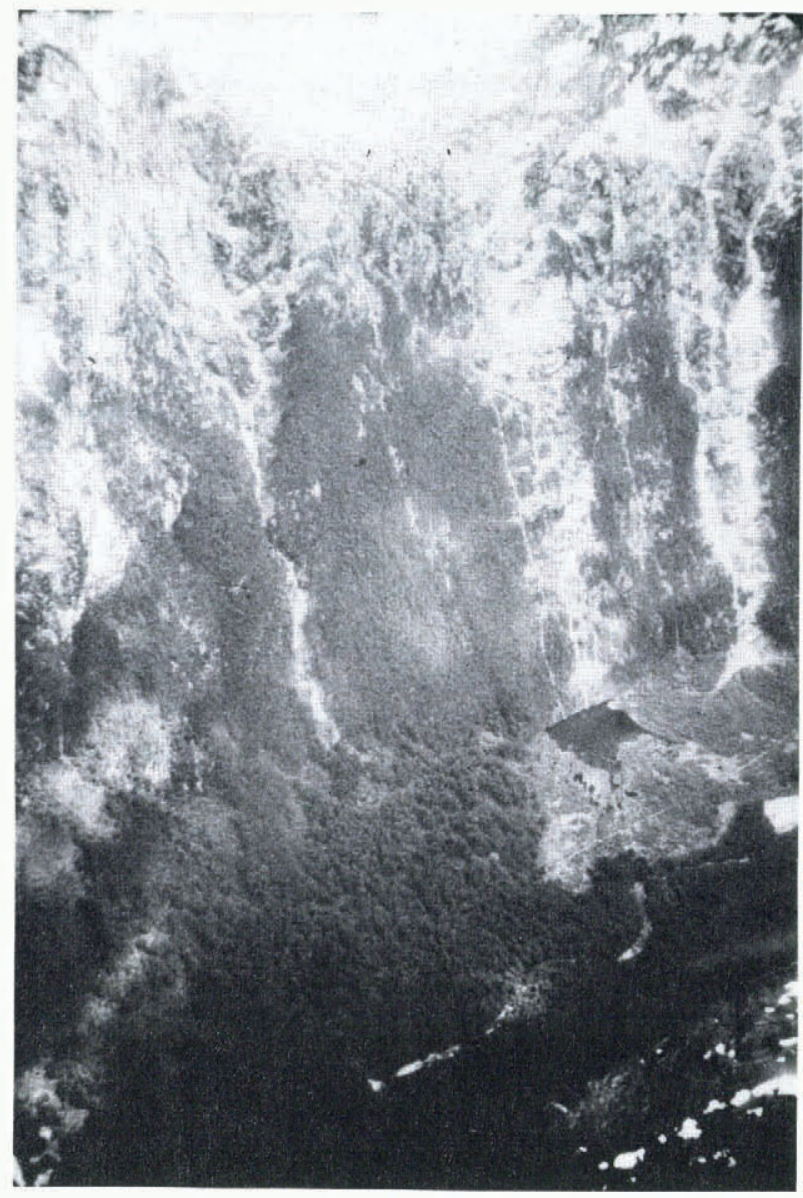

Fig. 4. Avalanche tarn called Hidden Lake which is No. of Table $I$. Note the debris free bedrock slope which continues to the level of the tarn and the radiating patterns of lesser tarns and vegetation. The Milford Track is the transverse line below Hidden Lake.

a radiating series of smaller tarns. When combined with the concentric patterns of vegetation, the evidence is consistent with that caused by ejecta flung outwards by the impact of large avalanches (Fig. 4). An avalanche fell into Hidden Lake in September 1983 and caused such a rapid evacuation of the water that the bridge over its outlet stream on the Milford Track was washed away.

Where a cone of avalanche snow frequently occurs, as near to tarn No. 3 (Fig. 5), a small rampart of debris can develop, as detritus rolls down and collects at its edge. When the snow melts, a small depression enclosed by the rampart and the valley wall may be created, which could fill with water. However the evidence from this site suggests this is not the mechanism for the formation of the tarns, because the location of the snow cone and the tarn are not the same.

There are two possible hypotheses as to why tarns form beneath only a small fraction of avalanche paths in the Fiordland region: (a) the profiles of paths with tarns favour the production of airborne avalanches which plunge directly to the valley floor with sufficient impact and frequency to excavate a depression; (b) while airborne avalanches are common in Fiordland (Smith, 1947), they do not usually produce impact depressions or pits because their force is dissipated by oblique impact on fan deposits lying against the base of the valley wall. A necessary condition for their formation is an abrupt break of slope at the valley floor. Those examined in the field were characterized by continuation of a debris-free

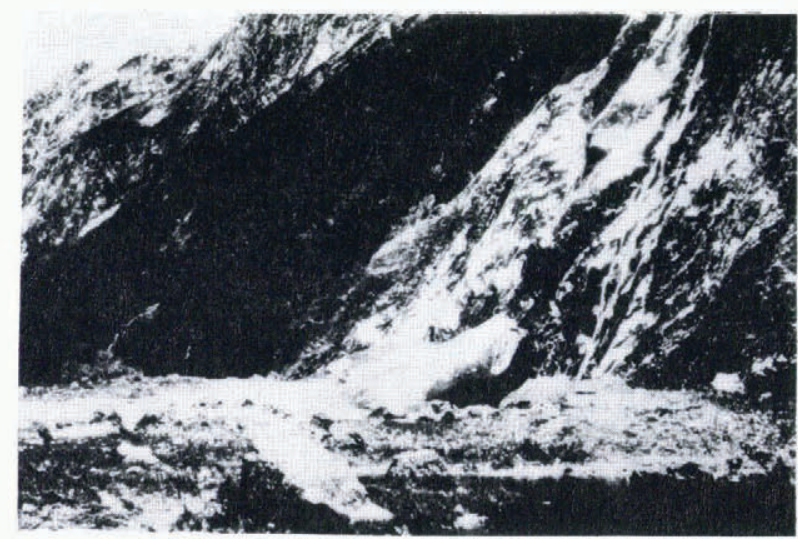

Fig. 5. Photograph showing avalanche snow and tarn at the "Swimming pool" (No. 2 of Table I). Together with damage caused by an avalanche the previous winter.

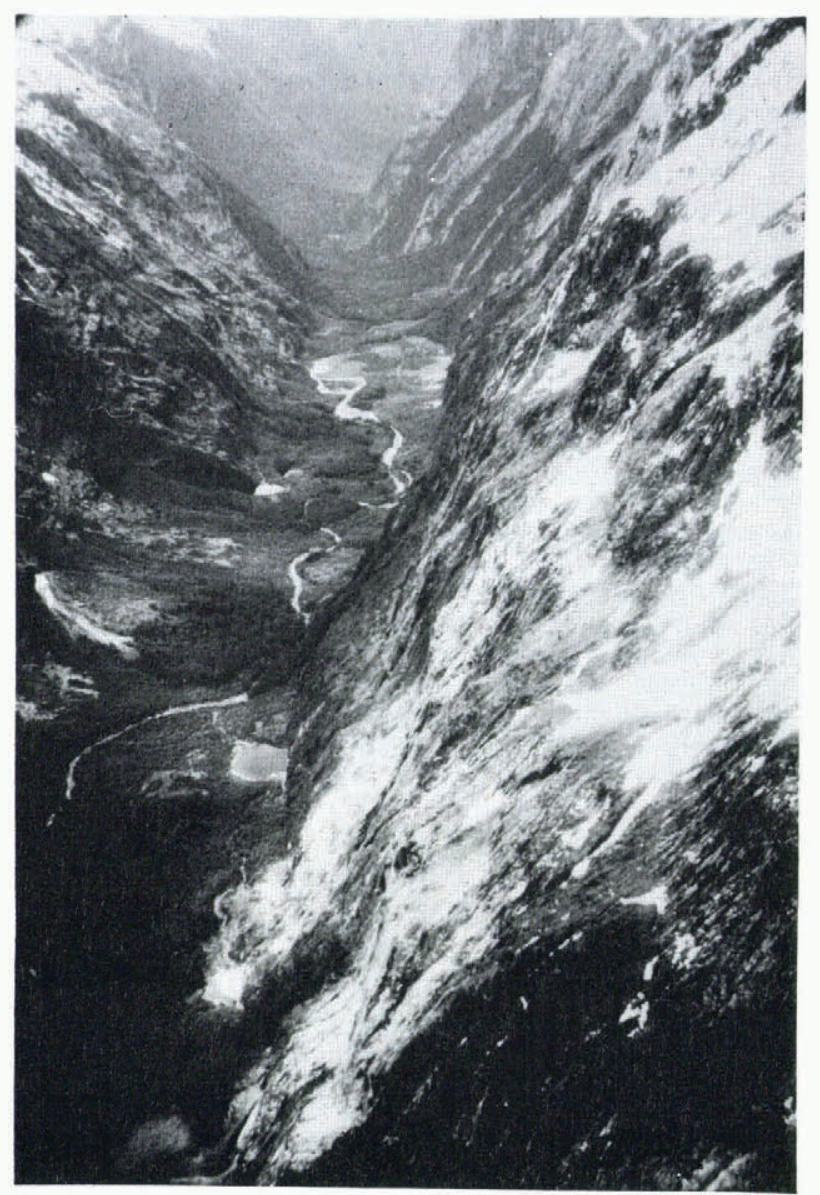

Fig. 6. Avalanche path in north branch of clinton valley illustrating steep nature of the track and tarn at its base (No. 4.)

bedrock slope to the level of the tarn, as illustrated in Figs 4-6.

Thus avalanche tarns only occur where there is little fan debris, either because it has been removed by the main river, or because the avalanche path produces little detritus for fan building. The latter possibility could be due to different rock types within the avalanche path, except that the tarns occur within at least four distinct rock lithologies ranging from igneous to metamorphic. Alternatively, debris produced in the avalanche-starting zones could be 
trapped in its snow-fields and not reach the valley floor. However an examination of starting zones in summer does not support this idea.

Snow avalanches can possess great destructive power with studies on impact pressures indicating probable values of 10 to $600 \mathrm{kN} / \mathrm{m}^{2}$ (Mellor, 1978; Lang and Brown, 1980). Shimizu and others (1980) report larger impact pressures of up to $1400 \mathrm{kN} / \mathrm{m}^{2}$ in the Kurobe Canyon of Japan, for high-speed avalanches (velocities of at least $60 \mathrm{~m} / \mathrm{s}$ ). From measurements with load cells, Schaerer and Salway (1980) consider that the initial peak pressure $P$ on a unit surface perpendicular to the direction of avalanche flow may be expressed as:

$$
P=c \rho v^{2}
$$

where $c$ is a coefficient dependent on the deformation of the snow (in turn a function of temperatures, freewater content, initial density, and the type and bonding of the snow grains), $\rho$ the density of the avalanche snow, and $v$ the avalanche speed.

If $v=60 \mathrm{~m} / \mathrm{s}, \rho=150 \mathrm{~kg} / \mathrm{m}^{3}$, and $c=1.5$ for large Fiordland avalanches, then $P=1080 \mathrm{kN} / \mathrm{m}^{2}$. Plunging avalanches strike the valley floors at angles of at least $38^{\circ}$ (Table I, Fig. 2) so that the impact pressures would be $P$ sin $38^{\circ}=665 \mathrm{kN} / \mathrm{m}^{2}$ or 1 arger. Smith (1947) describes a large avalanche near to tarn No. 10 of Table I, in which 280000 tonnes of snow fell $440 \mathrm{~m}$, apparently in free fall, into the Hollyford Valley below. At a point $130 \mathrm{~m}$ from impact, it destroyed a reinforced concrete structure built to protect the portal of a tunnel. The force at the structure is calculated by $\mathrm{Smith}$ to exceed $167 \mathrm{kN} / \mathrm{m}^{2}$. Impact pressures at the base of some Fiordland avalanche paths where there is an abrupt change of slope and rapid deceleration, may well exceed these values, and thus appear to be sufficient to cause the impact pits occupied by avalanche tarns.

Because the avalanche tracks in Fiordland are very steep, and the avalanches sometimes fall free, the validity of Equation (1) is uncertain. There appear to be few observations and little theory of the dynamics of plunging avalanches. As Schaerer (1962) points out, a jumping avalanche would also cause a vertical moving load and a friction load. In addition, the influence of high water pressures as the avalanche violently expels the contents of the tarn could be considered.

\section{CONCLUSIONS}

The avalanche tarns in the Fiordland region of New Zealand are large and are distributed about the most heavily glaciated part of the region. They occur at the base of slopes steeper than $38^{\circ}$ where there is an abrupt change of angle with the valley floor. Avalanche tarns are only found where deep glacial erosion in resistant rocks has created convex avalanchepath profiles which allow snow to plunge directly onto the valley floor. The evidence of concentric mounds of debris, together with radial bands of minor tarns, indicates that they are the product of violent avalanche impact. A necessary condition for their formation is that there is little or no fan debris to deflect the impact of the avalanche. Impact pressures have yet to be measured for large plunging avalanches of the type that appear to have produced the tarns described here, but could indicate upper limits to the destructive power of falling snow. The dynamics of such events also needs further study.

\section{REFERENCES}

Corner, G.D. 1980. Avalanche impact landforms in Troms, north Norway. Geografiska Annaler, Vol. 62A, Nos. $1-2$, p. 1-10.

Davis, G.H. 1962. Erosional features of snow avalanches, Middle Fork Kings River, California. U.S. Geological Survey. Professional Paper 450-D, p. D122-25.

Fitzharris, B.B., and Owens, I.F. 1980. Aval anche atlas of the Milford Road and an assessment of the hazard to traffic. New Zealand Mountain Safety Council. Avalanche Committee Report No. 4.

Lang, T.E., and Brown, R.L. 1980. Numerical simulation of snow avalanche impact on structures. U.S. Dept. of Agriculture. Forest Service. Research Paper RM-216.

Liest $\phi 1,0$. [1974.] Avalanche plunge-pool effect. Norsk Polarinstitutt. Arbok, 1972, p. 179-81.

Luckman, B.H. 1977. The geomorphic activity of snow avalanches. Geografiska Annaler, Vol. 59A, Nos. $1-2$, p. 31-48.

Mellor, M. 1978. Dynamics of snow avalanches. (In Voight, B., ed. Rockslides and avalanches. 1. Natural phenomena. Ansterdam, etc., El sevier Scientific Publishing Co., p. 753-92.)

Miller, L., and others. 1976. Avalanche atlas, San Juan county, Colorado, by $i$. Miller, B.R. Armstrong, and R.L. Armstrong. University of Colorado. Institute of Arctic and Alpine Research. Occasional Paper No. 17.

New Zealand Meteorological Service, 1973. Rainfall normals for New Zealand 1941 to 1970. New Zealand Meteorological Service. Miscellaneous Publication 145.

Peev, Kh. D. 1966. Geomorphic activity of snow avalanches. Union de Géodésie et Géophysique Internationale. Association Internationale d'Hydrologie Scientifique. Commission pour la Neige et la Glace. Division Neige Saisonnière et Avalanches. Symposium international sur les aspects scientifiques des avalanches de neige 5-10 avril 1965, Davos, Suisse, p. 357-68. (Publication No. 69 de l'Association Internationale d'Hydrologie Scientifique.)

Perla, R.I., and others. 1978. Impact force of snow, by R.I. Perla, T. Beck, and J. Banner. Ottawa, Environment Canada. Inland Waters Directorate. National Hydrology Research Institute. (National Hydrology Research Institute Paper No. 2; Inland Waters Directorate Scientific Series, No. 97.)

Rapp, A. 1959. Avalanche boulder tongues in Lappland: a description of little-known landforms of periglacial debris accumulation. Geografiska Annaler, Vo1. 41, No. 1, p. 34-48.

Schaerer, P.A. 1962. Avalanche defences for the TransCanada Highway at Rogers Pass. Canada. National Research Council. Division of Building Research. Technical Paper No. 141.

Schaerer, P.A., and Salway, A.A. 1980. Seismic and impact-pressure monitoring of flowing avalanches. Journal of Glaciology, Vol. 26, No. 94, p. 179-87.

Shimizu, H., and others. 1980. A study of high-speed avalanches in the Kurobe Canyon, Japan, by H. Shimizu [and 5 others]. Journal of Glaciology, Vol. 26 , No. 94, p. 141-51.

Smith, H.W. 1947. Avalanches. New Zealand Engineering, Vol. 2, May 10, p. 491-96. 